\title{
A Comparative Analysis of the Determinants of Interest Rate Risk Using the Example of Banks from Developed and Developing Financial Markets
}

\author{
Zeljko Racic ${ }^{1}$, Nemanja Stanisic ${ }^{2}$, Marijana Racic ${ }^{3}$ \\ ${ }^{1}$ Higher School of Professional Business Studies \\ Vladimira Perica Valtera 4, Novi Sad, Serbia \\ E-mail.raciczeljko@gmail.com \\ ${ }^{2}$ Singidunum University \\ Danijelova 32, Belgrade, Serbia \\ E-mil.nstanisic@singidunum.ac.rs \\ ${ }^{3}$ Ernst \& Young $\mathrm{GmbH}$ \\ Arnulfstraße 59, 80636 München, Germany \\ E-mail.Marijana.Racic@de.ey.com \\ cross $^{\text {ref }}$ http://dx.doi.org/10.5755/j01.ee.25.4.3112
}

The aim of this paper is to estimatethe effects of different balance sheet determinants on the interest rate risk exposure of banks operating in developed and developing financial markets. The quantification of the analysed exposure contributes to the process of identifying, monitoring and managing interest rate risk. As a sample of a developed financial market we surveyed 65 bank holding companies in the United States, whereas the sample of a developing financial market included 10 banks from the Republic of Serbia, which are listed on the Belgrade Stock Exchange. A comparative analysis of the influence of the balance sheet characteristics was conducted on the basis of the results of Stone's regression model and the Econometric panel model. Based on the obtained regression coefficients, we conclude that growth of total assets in banks in the United States results in increases in exposure to interest rate risk, while in Serbia the relationship seems to be inverse. Furthermore, the results show that an increase in the share of deposits in total assets of the U.S. banks reduces exposure to interest rate risk, while banks in the Republic of Serbia experience an opposite effect. The coefficients also suggest that there are some empirical factors whose effects are universal. For instance, both an increase in return on average equity (ROAE) and a decrease in net interest income lead to reductions of interest rate sensitivity, regardless of the level of development of the market where the banks operate.

Keywords: Financial Markets, Interest Rate Risk, Banks, Balance Sheet Characteristics, Panel Research.

\section{Introduction}

Interest rate risk is one of the key forms of financial risk that banks encounter in their business operations (Ivanovic, 2009; Bodie et al., 2009). Numerous factors have recently attached greater significance to interest rate risk management. The increase in interest rate volatility in the financial markets caused by the economic crisis of 2008 has contributed to the instability of income, costs and economic value of banks, whereas interest rate income has remained the most important source of income to banks. It is worthwhile pointing out that the regulatory framework of business defined by the Basel Accords (Basel II, Basel III) requires that reserves should be set aside according to the assessed market risk exposure, which also influences raising the question of interest rate analysis and management. The exposure of banks to interest rate risk has been the subject of research since 1970s. Many prominent authors have, by the application of Stone's Two- Index Model of Returns (Stone, 1974), investigated the relationship between interest rate and banks' stock returns (Flanery \& James, 1984; Faff \& Howard, 1999; Fraser et al., 2002, Au Young et al., 2007; Ballester et al., 2008). Stone's model was the basis for developing two approaches in investigating the influence of interest rate risk on banks' stock returns. The first approach is based on investigating the relationship between interest rate volatility and imbalances in maturity of assets and liabilities of the balance sheet. The pioneers of this approach were Flanery \& James (1984), who first provided empirical evidence of links between unanticipated interest rate movements and banks' stock returns. The results supporting the existence of the negative correlation between unanticipated interest rate movements and banks' stock returns have been confirmed in the studies of many authors (Yourougou, 1990; Kwan, 1991; Akella \& Greenbaum, 1992). The other approach in investigating the influence of interest rate risk on the banking sector is based on the identification and analysis of the influence of other determinants for the exposure of the bank to interest rate risk. Authors (Drakos, 2001; Fraser, 2002; Haq, 2007; Saporoschenko, 2002; Reichert \& Shyu, 2003; Au Yong et al., 2007, Lileikiene \& Likus, 2011) have discovered statistically significant links between bank exposure to interest rate risk and other numerous balance sheet characteristics like bank size, working capital, equity capital, non- interest income, off-balance sheet activities, deposit on total asset ratio, loans to total asset ratio, etc. 
This paper has two aims. The first aim is to identify factors which have a statistically significant influence on bank exposure to interest rate risk, after a quantitative assessment. The second aim is to carry out the comparative analysis of the nature and intensity of this influence on the banks operating in the developed and developing financial markets. The financial market of the United States has been taken as an example of a developed market, whereas the financial market of the Republic of Serbia has been cited as an example of a developing market.

\section{Data and Methodology}

The first part of the model applied in the paper is based on the application of Stone's linear two-index regression model. (Stone, 1974). The aim of the model application is to determine how changes in interest rate affect banks' stock returns (Elyasiani \& Mansur, 2004). Starting from the fact that risk and potential return are positively correlated, it may be said that the regression coefficient, which is placed by the variable denoting interest rate variations, represents a quantitative measure of bank exposure to interest rate risk. Stone's regression model can be represented by the following (Kwan, 1991):

$$
\hat{R}_{j t}=\beta_{0 j}+\beta_{1 j} \hat{R}_{m t}+\beta_{2 j} \hat{R}_{i t}+\hat{\varepsilon}_{j t}
$$

$\mathrm{R}_{\mathrm{jt}}$ - the holding period return to the $\mathrm{j}$ - th bank's common stock over the period ending at time $t$,

$\mathrm{R}_{\mathrm{mt}}$ - the holding period return to the market portfolio over the period ending at time $t$,

$\mathrm{R}_{\mathrm{it}}$ - the holding period return on an index of constant maturity risk-free zero bonds (interest rate approximation),

$\beta_{1 j}$ - regression coefficient which assesses the sensitivity of stock return to the unit change of $\mathrm{R}_{\mathrm{mt}}$, and,

$\beta_{\text {it }}$ - regression coefficient which assesses the sensitivity of stock return to the unit change of $\mathrm{R}_{\mathrm{it}}$.

In the context of Stone's model, the value of $\beta_{2 j}$ represents a response of holding period return of banks' common stocks to the changes in interest rates taking into account the simultaneous influence of the overall capital market. Since the holding period return of treasury bonds is negatively correlated with interest rate changes, the positive value of $\beta_{2 \mathrm{j}}$ indicates that holding period return to banks common stocks and interest rates are negatively correlated. In case the correlation coefficient between dependent variables of the model is high, market index orthogonalization is applied. This means replacing the original values of the $\mathrm{R}_{\mathrm{mt}}$ variable with the residuals of the model of returns, which can be represented by the following:

$$
\hat{R}_{m t}=\beta_{1 j} \hat{R}_{i t}+\hat{\varepsilon}_{j t}
$$

The dependent variable of Stone's model is the variation of holding period return to banks common stocks in a seven-day period. As for the US banks, the weekly data on holding period return to banks common stocks are taken from Thomson's data stream database. In the case of the banks from the Republic of Serbia, the holding period return to banks common stocks is calculated according to the data from the Belgrade Stock Exchange using weekly changes in prices of bank shares.
To assess the influence of the capital market on the exposure to interest rate risk of the US banks, the weekly returns on the S\&P 1500 Composite index are used. The companies whose shares compose the index cover $95 \%$ of the market capitalisation, which makes this index an adequate indicator of the overall capital market in the USA. The data on weekly index price movement is taken from Thomson's data stream database. In the case of the Republic of Serbia, the changes in the capital market are monitored on the basis of weekly return variations on the Belex 15 market index, which represents a reliable analytical tool for analysing and monitoring the performances of the most liquid segment of the market (Jeremic, 2009). The weekly return on the Belex 15 is calculated according to the data in its weekly prices taken from the Belgrade Stock Exchange. The analysis of the influence of changes in interest rates on the holding period return to banks common stocks is conducted according to the variations of yield to maturity of long-term zero-coupon bonds (Saunders \& Cornet, 2011). This concept of yield to maturity represents the most accurate measure of interest rates (Mishkin, 2006). In the case of the US financial market, ten-year constant maturity risk-free zero coupon bonds were observed, whereas for the Republic of Serbia the yield to maturity of A2016 bonds, issued by the Republic of Serbia with the aim to cover the debt outstanding for the "old" foreign currency savings. According to the weekly changes of returns at maturity, the variable "yield relative" was designed (Flanery \& James, 1984):

$$
\text { yieldrelative }=-\left[\frac{Y T M_{t}-Y T M_{t-1}}{Y T M_{t-1}}\right]
$$

The negative sign of the variable "yield relative" derives from the theoretical standpoint about the existence of negative correlation between the movement of interest rate and returns on the bonds.

The other part of the model applied in this paper is based on the application of econometrical panel model. The procedure of panel research represents a choice and analysis of the model which best denotes the observed relationships (Baum, 2006). The selection between the Pooled, Fixed or Random effects models is carried out according to the results of Hausman and Breusch Pagan tests. The aim of the application of the econometrical panel model is to assess the nature and intensity of the influence of independent variables on annual values of the coefficient $\beta_{i t}$, which represents a quantitative measure of the exposure of banks to interest rate risk (Ballester et al., 2009; Haq, 2007). The analysed model can be described by the following equation:

$$
\begin{aligned}
& \beta_{\mathrm{it}}=\alpha_{0}+\alpha_{1} \text { size }_{\mathrm{it}}+\alpha_{2} \text { cap }_{\mathrm{it}}+\alpha_{3} \text { loans }_{\mathrm{it}}+\alpha_{4} \text { depo }_{\mathrm{it}}+ \\
+ & \alpha_{5} \operatorname{nir}_{\mathrm{it}}+\alpha_{6} \text { nii }_{\mathrm{it}}+\alpha_{7} \text { roae }_{\mathrm{it}}+\alpha_{8} \text { sum_der }_{\mathrm{it}}+\omega_{\mathrm{it}}
\end{aligned}
$$

$\beta_{\text {it }}$ - quantitative measure of bank's exposure to interest rate risk over the year t;

vel - Ln (Assets);

cap - Equitu/ Total Assets;

loans - Loans/ Total Assets;

depo - Deposits/ Total Assets;

nir - Net Interest Revenue/ Average Assets;

nii - Non Interest Income/ Net Income;

roae - Return on Average Equity;

sum_der- Derivetives/ Total Assets. 
When specifying the presented regression panel model a consideration of the influence of variations in balance sheet sums on the exposure to interest rate risk was avoided due to the fact that the values of natural logarithms of annual balance sheet sums of banks are not within the application area of other variables of the model. Therefore the influence of the variable size on the exposure to interest rate risk assessed by a special regression panel model whose results are analysed in the comparative analysis.

\section{The Results of the Application of the Model}

The application of Stone's regression model on the sample of 65 US banks in the period between 2001 and 2010, after removing multicollinearity, autocorrelation and heteroscedasticity (White, 1980; Newey \& West, 1987), has resulted in the estimates of coefficient which are mostly negative, which indicates a positive correlation between HPR banks and interest rate, i.e. the structure of the balance sheet where the duration of the liabilities is longer than duration of the assets (Racic, 2013). It is important to emphasize that due to the relatively high value of the correlation coefficient between independent variables of the model $(\rho=0,4)$ orthogonalization of the market index occurred, which contributed to an increase in statistical significance of the estimates as well as to changes in the sign of $\beta_{\text {it }}$ in most cases. Orthogonalization is a procedure for removing multicollinearity which completely eliminates the correlation between independent variables in the regression model. Despite the fact that there is a theoretical link between the capital market and interest rates, many authors used the procedure of orthogonalization as a legitimate statistical option in their empirical research (Kwan, 1991).

Respecting the limits that the elimination of correlation between independent variables of Stone's regression model brings, the economic interpretation of the results of the panel research in the case of US banks starts from the negative value of the coefficient $\beta_{i t}$. The application of the Econometrics panel model has resulted in the estimates of the coefficients presented in Table 1.

Table 1

The results of the application of the multiple Econometrics panel model on the sample of US banks

\begin{tabular}{|c|c|c|c|c|c|c|c|c|}
\hline Varijabla & cons $\left(\boldsymbol{\alpha}_{\mathbf{0}}\right)$ & cap $\left(\boldsymbol{\alpha}_{\mathbf{1}}\right)$ & loans $\left(\boldsymbol{\alpha}_{\mathbf{2}}\right)$ & depo $\left(\boldsymbol{\alpha}_{\mathbf{3}}\right)$ & nir $\left(\boldsymbol{\alpha}_{\mathbf{4}}\right)$ & nii $\left(\boldsymbol{\alpha}_{5}\right)$ & roae $\left(\boldsymbol{\alpha}_{\mathbf{6}}\right)$ & sum_der $\left(\boldsymbol{\alpha}_{7}\right)$ \\
\hline Coef. & $-1,0462^{* * * *}$ & $-0,995$ & 0,207 & $0,465^{* *}$ & $-5,914^{*}$ & 0,0002 & $1,770^{* * *}$ & $-0,0067^{*}$ \\
\hline Std. Err. & $(0,178)$ & $(0,855)$ & $(0,169)$ & $(0,213)$ & $(3,501)$ & $(0,0009)$ & $(0,183)$ & $(0,0039)$ \\
\hline
\end{tabular}

(*-significance $90 \%$; **- significance $95 \%$; ***- significance $99 \%$ ).

With respect to the joint effect of all factors on the exposure of banks to interest rate risk, the estimates of regression coefficients leads to several conclusions. The first statistically significant factor which has impact on the exposure of banks to interest rate risk is the share of the deposits in relation to the total assets of the banks. Due to its savings nature, the deposit base is a stable and relatively inexpensive source of financing for US banks. According to the value of $\alpha_{3}=0,465$ it is possible to make a conclusion at the level of $95 \%$ significance that there is a negative correlation between the variation of the deposit share in the total balance sheet sum and exposure of banks to interest rate risk. These results are in accordance with the theoretical standpoints stating that a larger deposit share in the balance sheet sum decreases dependence from external sources of financing, which contributes to a decrease in the exposure of US banks to interest rate risk. The value of the coefficient $\alpha_{5}=-5,914$ at the level of $90 \%$ significance confirms that there is a strong positive link between the net interest income and the exposure of banks to interest rate risk.An increase in the net interest income in relation to the balance sheet sum may be achieved by an increase in the loan share within the total assets of the balance sheet and/or by an increase in interest spread. In the case of lending activities of US banks, the given period saw a slight fall in the loan share within the assets, which caused a decrease in the exposure to interest rate risk. Likewise, the development of US financial market has resulted in an increase in costs of securing the finance sources and lower loan income, which had a further influence on a decrease in interest spread and exposure to interest rate risk. It is, however, important to point out that a decrease in lending and pressure on the interest spread indicate the "disappearance" of traditional bank operations in the USA. Return on Average Equity (ROAE) is the next factor which, by respecting the joint effect of the other analysed factors, has an influence on a decrease in the exposure of banks to interest rate risk. According to the value of coefficient $\alpha_{7}=1,770$ it can be stated that there is a strong statistically negative link between variations in ROAE and exposure of banks to interest rate risk. This means that an increase in ROAE protects banks from negative scenarios which can be caused by unexpected changes of interest rates. The last statistically significant factor included in the research is the relationship between interest rate derivatives and balance sheet sums of banks. Due to increasing competition, banks are trying to generate income based on off- balance sheet activities. In addition to income from fees and loans, they often take speculative trading activities with instruments primarily used for hedging. The value of the coefficient $\alpha_{8}=-0,0067$ at a $90 \%$ significance level testifies that there is a positive, although weak, link between derivative activities of banks and exposure to interest rate risk. The positive link between the use of interest rate derivatives and exposure to interest rate risk confirms that banks use interest rate derivatives mainly for speculative purposes.

As for the Serbian financial market, the application of Stone's regression model on the sample of 10 banks listed on the Belgrade Stock Exchange in the period between 2006 and 2010 resulte in estimates of coefficients that in most cases have positive signs, after eliminating heteroscedasticity and autocorrelation, (Newbold, 2010). This indicates the existence of a negative correlation between banks' stock returns and interest rate, or in other words, the existence of maturity composition where the duration of assets exceeds the duration of liabilities. Due to 
the low value of the correlation coefficient between returns on market index and returns on government bonds $(\rho=$ $0,0164)$, there was no need to apply the procedure of orthogonalization. Taking into account the annual values of the regression coefficient $\beta_{i t}$, we assessed the influence of the observed factors on the exposure to interest rate risk for banks in the Republic of Serbia. The results of the application of multiple Econometric panel model are presented in Table 2.

Table 2

The results of the application of the multiple Econometrics panel model on the sample of banks in the Republic of Serbia

\begin{tabular}{|c|c|c|c|c|c|c|c|c|}
\hline Varijabla & cons $\left(\boldsymbol{\alpha}_{0}\right)$ & cap $\left(\boldsymbol{\alpha}_{1}\right)$ & loans $\left(\boldsymbol{\alpha}_{2}\right)$ & depo $\left(\boldsymbol{\alpha}_{3}\right)$ & nir $\left(\boldsymbol{\alpha}_{4}\right)$ & nii $\left(\boldsymbol{\alpha}_{5}\right)$ & roae $\left(\boldsymbol{\alpha}_{\mathbf{6}}\right)$ & trans_depo $\left(\boldsymbol{\alpha}_{7}\right)$ \\
\hline Coef. & $-0,654^{*}$ & $-0,789$ & 0,227 & $0,854^{* *}$ & $5,891^{* *}$ & $-0,002$ & $-0,458^{* *}$ & $-1,149^{*}$ \\
\hline Std. Err. & $(0,364)$ & $(0,845)$ & $(0,364)$ & $(0,334)$ & $(2,797)$ & $(0,002)$ & $(0,221)$ & $(0,575)$ \\
\hline
\end{tabular}

(*-significance $90 \%$; **-significance $95 \%$; ***-significance $99 \%$ ).

While recognizing the simultaneous effect of all factors on the exposure of the banks to interest rate risk, the estimates of regression coefficients lead to several conclusions. A rise in the share of total deposit in the balance sheet sum increases the exposure of the banks to interest rate risk. The structure of deposits of banks in the Republic of Serbia mainly consists of deposits with a maturity period not longer than three months, which increases the current positive maturity gap and this further exposes banks to interest rate risk. In addition to short term deposits, the reason for this nature is a high cost of deposits paid by a domestic bank due to the high risk of the country (BB minus) and the lack of funds on the capital market at the global level. According to the value of the coefficient $\alpha_{3}=0.854$, at a level of $95 \%$ significance it can be concluded that a rise in the share of total deposits in the balance sheet sum within the balance sheet by $1 \%$ increases the exposure of the bank to interest rate risk to the extent of $0.854 \%$. The share growth in transaction deposit in the balance sheet sum has an impact on reducing the exposure of the banks to interest rate risk. Transaction deposits are free funding sources for banks, which make them independent from variations in interest rates. According to the value of the coefficient $\alpha_{7}=-1,149$ it can be concluded at the level of $90 \%$ significance that the increased share of transaction deposits in the balance sheet sum by $1 \%$ leads to the reduction in the exposure of the bank to interest rate risk to the extent of $1,149 \%$. Another important factor is the net interest income whose growth with respect to the balance sheet sum affects an increase in the exposure to of the banks to interest rate risk. An increase in the lending of the banks affects the growth of the positive maturity gap in the banking sector in the Republic of Serbia. Therefore, according to the coefficient $\alpha_{4}=5,891$, at a $95 \%$ significance level, it can be concluded that an increase in net interest income in relation to the total assets by $1 \%$ leads to an increase in the exposure of the bank to interest rate risk, to the extent of 5,89\%. Finally, the last factor analyzed which has a significant influence on the observed relationships is return on average equity (ROAE), whose growth has an impact on reducing the exposure of the bank to interest rate risk. According to the estimates of the regression coefficient $\alpha_{6}=-0,458$, at a $90 \%$ significance, level, it can be concluded that the growth of ROAE by $1 \%$ reduces the exposure of the bank to interest rate risk to the extent of $0,458 \%$.

\section{A Comparative Analysis of the Stone and Panel Models of Returns in Serbian and U.S. Banks}

The results of the application of Stone's regression model on the sample of developed and developing financial markets differ in several segments. The first significant difference is related to the sign of the regression coefficient $\beta_{\text {it }}$. In the case of the U.S. banks the estimates of the coefficient are mostly negative, while the coefficientshave a positive sign in the case of Serbian banks. On the basis of the existence of the negative maturity composition in the structure of assets and liabilities, it can be concluded from a speculative aspect that the U.S. banks in the given period mainly expected the growth of interest rates. Unlike the U.S. banks, which plan hedging usually on the use of interest rate derivatives (Reichert \& Shyu, 2003; Zhao \& Moser, 2006), the banks in the Republic of Serbia, due to an underdeveloped derivatives market, oriented hedging measures within Asset-Liability Management. A positive value of the regression coefficient $\beta_{\text {it }}$ testifies that, from the speculative aspect, domestic banks in the period between 2006 and 2011 had a balance sheet structure in line with expectations of a fall in interest rates. Such expectations proved justified in the conditions of the economic crisis, because in the observation period there was a falling trend of interest rates as a logical consequence of the need for additional liquidity in the real sector of the Republic of Serbia. Another significant difference in the results of the application of Stone's model refers to the size of the absolute value of the coefficient $\beta_{\mathrm{it}}$. The fact that the absolute value of the U.S. banks' $\beta_{\text {it }}$ takes much higher values than is the case with Serbian banks means that U.S. bank's stock returns respond more forcefully to changes in the returns of government bonds. This fact proves that banks operating in the United States are exposed to a greater extent to interest rate risk than banks operating in the financial market of the Republic of Serbia.This indicates that Serbian banks tend to do safer business operations. Expensive sources of capital and a considerable decline in the number of potential creditworthy borrowers are the main reasons for this. The second part of the study, which is based on the application of Econometric panel model, resulted in estimates of regression coefficients on which it is possible to identify some differences when it comes to the impact of the analysed factors on the exposure of banks from developed and undeveloped market to interest rate risk (Ballester et al., 2009). 
Comparative overview of regression coefficients for banks from the United States and the Republic of Serbia

\begin{tabular}{|l|c|c|c|c|c|c|c|c|c|}
\hline & cons & kap & kred & depo & nkm & nekam & roae & sum_der & trans_depo \\
\hline $\mathrm{SAD}\left(\beta_{\mathrm{it}}<0\right)$ & $-1,046^{* * *}$ & $-0,995$ & 0,207 & $0,465^{* *}$ & $-5,914^{*}$ & 0,0002 & $1,770^{* * *}$ & $-0,0067^{*}$ & - \\
\hline Serbia $\left(\beta_{\mathrm{it}}>0\right)$ & $-0,654^{*}$ & $-0,789$ & 0,227 & $0,854^{* *}$ & $5,891^{* *}$ & $-0,002$ & $-0,458^{* *}$ & - \\
\hline
\end{tabular}

The first significant difference is in favour of the claim that the total assets of U.S. banks increase their exposure to interest rate risk, while the situation with domestic banks is different. From the standpoint of reducing exposure to interest rate risk, it can be stated that the U.S. financial markets should apply strategies that lead to a reduction in the value of the Herfindahl-Hirschman index. Conversely, the study of the Serbian banking sector shows that the bigger banks are less exposed to interest rate risk. Due to the high cost of capital and scarce market of potential creditworthy borrowers, domestic banks withsmaller balance sheet sums are forced into risky business. This leads them to an increased risk of insolvency, which may undermine the stability of the entire banking sector. The conclusion is that in the financial market of the Republic of Serbia there are too many banks in relation to the needs of the market and that their number should be reduced. The following statistically significant factor is the share of deposits in the balance sheet sum. Deposits as a cheaper funding source should affect the reduction of dependence on external sources and thus reduce the exposure of the bank to interest rate risk. In the case of U.S. banks, it can be said that the impact of the increasing share of deposits in the balance sheet sum is in full compliance with the baseline assumption, whereas in the Republic of Serbia, the situation is completely different. A large proportion of short- term deposits in the total deposit base, as well as the high interest rates that banks pay for them, lead to the situation that a rise in the share of total deposits in the balance sheet sum increases the exposure of the bank to interest rate risk. This is supported by the fact that an increased share of transaction deposits, which are a free funding source for banks, reduces the exposure to interest rate risk. According to previous results, it can be concluded that the financial managers from banks in the Republic of Serbia should make every effort in order to find a less expensive deposit sources with longer maturities, which is difficult to achieve during the current economic crisis. The following statistically significant factor affecting the exposure of the bank to interest rate risk is the share of net interest income in total assets. As for banks from both financial markets, the growth of the share of net interest income leads to an increase in the exposure of the bank to interest rate risk. Therefore, if necessary the bank should reduce exposure to interest rate risk, reduce lending and/or make a better diversification of credit lending. Finally, the last factor included in the research which performs a statistically significant impact on the exposure of banks to interest rate risk is the return on average equity (ROAE). For banks from both markets, it can be concluded that the growth of ROAE reduces exposure to interest rate risk.

\section{Conclusions}

The results of the research suggest that the nature and intensity of the impact of certain balance sheet characteristics on the exposure of banks to interest rate risk depends on the degree of development of the analysed markets.

The banks with the largest balance sheet amounts operating on the U.S. financial market show less aversion to risk-taking in comparison to the major banks operating in the financial market of the Republic of Serbia. Large banks from developed financial markets have easier access to capital market, as well as the ability to use an economy of scale and economy of scope. Likewise, it is easier to take a speculative position and thus a "too big to fail" concept, which refers to the government guarantees that the solvency of major banks will be defended with the aim of protecting the overall financial system. Conversely, large banks operating in developing financial markets have limited access to the capital market. Countries whose financial markets are developing typically have a low credit rating. In times of economic crisis investors rarely invest in such financial markets, so banks are forced to have placements based on the deposits collected on the market where they operate. The lack of awareness of the high cost of capital causes banks from the developing financial market to have a tendency to conduct safer business regardless of the size of their assets. The interest rate that banks pay on deposits has a significant impact on the nature of their exposure to interest rate risk. The passive interest rate that banks pay on deposits of the United States is much lower than the interest rate paid on deposits by banks from the Republic of Serbia. Therefore it can be said that the growth of the deposits, as a cheap source of funds, decreases exposure to interest rate risk in the case of banks from developed financial market. However, high interest rate on deposits paid by banks from developing markets are an expensive source of funds so an increase in their share in the structure of liabilities increases exposure to interest rate risk.

Finally, the results of the research showed that there are empirical determinants of exposure to interest rate risk whose effect on the exposure of banks is of the same direction regardless of the development of financial markets where analysed banks operate. Therefore, an increase in the share of net interest income in the case of all banks increases the exposure to interest rate risk, whereas a rise in ROAE protects banks from this exposure. This means that, with the aim of reducing bank`s risk sensitivity to interest rate changes, profitability should be mostly based on the concept of traditional banking, the one which implies a widely diversified portfolio of low-risk loans financed by low-cost financing sources. 


\section{References}

Akella, S. R., \& Greenbaum, S. I. (1992). Innovations in Interest Rates, Duration Transformation and Banka Stock Returns. Journal of Money, Credit and Banking, 24, 27-42. http://dx.doi.org/10.2307/1992789

Au Yong, H. H., Faff, R., \& Chalmers, K. (2009). Derivative Activities and Asia Pacific banks Interest Rate and Exchange Rate Exposures. Journal of International Financial Markets, Institutions and Money, 19(1), 16-32. http://dx.doi.org/ 10.1016/j.intfin.2007.08.002

Ballester, L., Ferrer, R., Gonzales, C., \& Soto, M. G. (2009). Determinants of Interest Rate Exposure of Spanish Banking Industry, Department of Economics and Finance UCLM, 1-33. Available from internet: doi: 10.1016/j.intfin. 2007. 08.2002

Baum, C. F. (2006). An Introduction to Modern Econometrics Using Stata. Texas: College Station.

Bodie, Z., Kane, A., \& Marcus, A. J. (2009). Osnovi Investicija Sesto Izdanje. Beograd: DATASTATUS.

Drakos, K. (2001). Interest Rate Risk and Bank Common Stock Returns: Evidence from the Greek banking sector. Department of Economics: London Guildhall University.

Elyasiani, E., \& Mansur, I. (2004). Bank Stock Return Sensitivities to the Long term and Short term Interest Rate: A Multivariate GARCH Approach. Managerial Finance, 30, 32-45. http://dx.doi.org/10.1108/03074350410769263

Faff, R. W., \& Howard, P. F. (1999). Interest Rate Risk of Australian Financial Sector Companies in a Period of Regulatory Change. Pacific Basin Finance Journal, 7(1), 83-101. http://dx.doi.org/10.1016/S0927-538X(99)00002-5

Flannery, M. \& James, M. (1984). The Effect of Interest Rate Changes on the Common Stock Returns of Financial Institutions. The Journal of Finance, 39(4), 1141-1153. http://dx.doi.org/10.1111/j.1540-6261.1984.tb03898.x

Fraser, D. R., Madura, J., \& Weigand, R., A. (2002). Sources of Bank Interest Rate Risk. The Financial Rewiew, 37(3), 351-367. http://dx.doi.org/10.1111/0732-8516.00002

Haq, M. (2007). Factor Determining Bank risk: A European Perspective. Midwest Finance Association Conference.

Ivanovic, P. (2009). Upravljanje Rizicima u Bankama. Beograd: Beogradska Bankarska Akademija Fakultet za Bankarstvo, Osiguranje i Finansije.

Jeremic, Z. (2009). Finansijska Trzista. Beograd: Univerzitet Singidunum.

Kwan, S. H. (1991). Re-Examination of Interest Rate Sensitivity of Commercial Bank Stock Returns Using a Random Coefficient Model. Journal of Financial Services Research, 5(1), 61-76. http://dx.doi.org/10.1007/BF00127084

Lileikiene, A., \& Likus, A. (2011). Analysis of Change Effect in the Market Interest Rate on Net Interest Income of Commercial Banks. Engineering Economics, 22(3), 241-254. http://dx.doi.org/10.5755/j01.ee.22.3.514

Mishkin, S. F. (2006). Monetarna Ekonomija, Bankarstvo i Finansijska Trzista- Sedmo Izdanje. Beograd: DATASTATUS.

Newbold, P., Carlson, W. L., \& Thorne, B. (2010). Statistika za Poslovanje i Ekonomiju, Zagreb: MATE.

Newey, W., K., \& West, K. D. (1987). A Simple, Positive Semi-Definite, Heteroskedasticity and Autocorrelation Consistent Covariance Matrix, Econometrica, 55(3), 703-708. http://dx.doi.org/10.2307/1913610

Racic, Z. (2013). Komparativna Analiza Uticaja Velicine Banaka na Izlozenost HPR a Kamatnom Riziku: Razvijeno Finansijsko Trziste vs. Finansijsko Trziste Republike Srbije, Skola Biznisa, 1, 1-11. http://dx.doi.org/10.5937 /skolbiz1301001R

Reichert, A., \& Shyu, Y. (2003). Derivative Activities and the Risk of International Banks: A Market Index and VaR Approach. International Rewiew of Financial Analysis, 12(6), 489-511. http://dx.doi.org/10.1016/S1057-5219(03) 00061-9

Saporoshenko, A. (2002). The Sensitivity of Japanese bank Stock Return to Economics Factors An Examination of Asset/ Liability Differences and Main bank status. Global Finance Journal, 13(2), 253-270. http://dx.doi.org/10.1016/ S1044-0283(02)00043-1

Saunders, A., \& Cornet, M. M. (2011). Financial Institutions Management- A risk Management Approach. International Edition: McGraw-Hill.

Stone, B. (1974). Systematic Interest Rate Risk in a Two-Index Model of Returns. Journal of Financial and Quantitative Analysis, 9(5), 709-721. http://dx.doi.org/10.2307/2329656

Yourogou, P. (1990). Interest - Rate Risk and the Pricing of Depository Financial Intermediary Common Stock: Empirical Evidence. Journal of Banking and Finance, 14(4), 803-820. http://dx.doi.org/10.1016/0378-4266(90)90077-F

White, H. (1980). A Heteroskedasticity-Consistent Covariance Matrix Estimator and a Direct Test for Heteroskedasticity. Econometrica, 48(4), 817-838. http://dx.doi.org/10.2307/1912934

Zhao, F., \& Moser, J. (2006).Use of Derivatives and Bank Holding Company Interest Rate Risk. FMA: Annual Meeting.

The article has been reviewed.

Received in December, 2012; accepted in October, 2014. 